Article

\title{
Influence of Nonthermal Atmospheric Plasma-Activated Water on the Structural, Optical, and Biological Properties of Aspergillus brasiliensis Spores
}

\author{
Se Hoon Ki ${ }^{1,+}{ }^{(}$, Hyeongjin Noh ${ }^{2,+} \oplus$, Geum Ran Ahn ${ }^{2}\left(\mathbb{D}\right.$, Seong Hwan Kim ${ }^{2, *}{ }^{\circ}$, \\ Nagendra K. Kaushik ${ }^{1}$, Eun Ha Choi ${ }^{1}$ 迥 and Geon Joon Lee ${ }^{1, *}$ \\ 1 Department of Electrical and Biological Physics/Plasma Bioscience Research Center, Kwangwoon University, \\ Seoul 01897, Korea \\ 2 Department of Microbiology and Institute of Biodiversity, Dankook University, Cheonan 31116, Korea \\ * Correspondence: piceae@dankook.ac.kr (S.H.K.); gjlee@kw.ac.kr (G.J.L.); Tel.: +82-41-550-3454 (S.H.K.); \\ +82-2-940-8619 (G.J.L.) \\ + Equally contributed.
}

Received: 23 August 2020; Accepted: 10 September 2020; Published: 13 September 2020

\begin{abstract}
Plasma-activated water (PAW) has emerged as a platform for sterilizing fungal pathogens. In this study, we investigated the influence of PAW on black melanized spores of Aspergillus brasiliensis to explore the mechanism of fungal spore inactivation. PAW was prepared by activating deionized water with a nonthermal atmospheric pressure air plasma jet (soft plasma jet). The concentrations of $\mathrm{H}_{2} \mathrm{O}_{2}$ and $\mathrm{NO}_{x}$ in the PAW treated by the soft plasma jet for 3 min were $50 \mu \mathrm{M}$ and $1.8 \mathrm{mM}$, respectively, and the $\mathrm{pH}$ of the $\mathrm{PAW}$ was 3.10. The reactive oxygen and nitrogen species (RONS) in the PAW increased with longer plasma activation time. After being treated for $30 \mathrm{~min}$ in the PAW with a plasma activation time of $3 \mathrm{~min}$, the spore viability dramatically dropped to $15 \%$. The viabilities of $0.3 \% \mathrm{H}_{2} \mathrm{O}_{2}$ - and $0.3 \% \mathrm{HNO}_{3}$-treated spores were $22 \%$ and $42 \%$, respectively. The breakage of the spore cell wall by the PAW was revealed in scanning electron microscope images and flow cytometry measurements. Disruption of cell wall integrity provides a path for intracellular components to escape and RONS of the PAW can attack intracellular components directly. Degradation of high molecular genomic DNA was also observed by agarose gel electrophoresis. These results suggest that long-lived reactive species generated in the PAW play an important role in the inactivation of melanized fungal spores. Consequently, PAW produced by a soft plasma jet can be applied to sterilize bioprotective walled fungal spores in a relatively large volume.
\end{abstract}

Keywords: Aspergillus brasiliensis; plasma-activated water; cell wall integrity; DNA degradation; fungal spore inactivation; reactive oxygen species; reactive nitrogen species

\section{Introduction}

Fungi are eukaryotic organisms that grow with hyphal cells and produce spores. They have evolved diverse morphological and genetic groups that are estimated to include 1.5-5.0 million species on earth [1]. They play key roles in natural ecosystems as material decomposers, mutualists with other organisms, and pathogens of animals, plants, and humans [2]. As plant pathogens, their increased infection on agricultural crops has been threatening food security worldwide [3]. Furthermore, the increase and broadening of their infection on wild host species have brought about severe die-offs and extinctions in some species [4]. As human pathogens, fungi can infect different parts of the human body such as lung, skin, and brain $[5,6]$. Infections of the membranes surrounding the spinal cord and brain and blood stream 
are less common than skin and lung infections but can be detrimental and fatal. Invasive pathogenic fungi can cause disease in healthy people and opportunistic fungal pathogens infect individuals already experiencing severe illness. Many fungi form small round airborne dispersal spores, which are produced from hyphal cells. Fungal spores dispersed through the air can adhere to medical devices and the surface of vegetables and fruits during food processing. Thus, fungal spores found in both indoor and outdoor environments have an infective potential in personal and public health and a contamination potential in food spoilage $[7,8]$. The management of fungal spores has been essential in the medical and food industry for the protection of human health and control of food hygiene. Diverse approaches including biological, chemical, and physical methods such as antifungal agents, photodynamic therapy, ultra-violet (UV) light sterilizer, and plasma treatment have been applied for fungal spore inactivation [9-11]. However, the application of each method has merits and demerits.

Recently, the effects of nonthermal atmospheric pressure plasma jets (NTAPPJ) on fungi have attracted considerable attention. An atmospheric pressure plasma jet or dielectric barrier discharge (DBD) plasma has been used for sterilization, inactivation, and cancer treatment [11-19]. We have been working on the effects of plasma treatment on the viability of fungal spores as a plasma sterilizer for fungal pathogens [19-22]. The atmospheric pressure plasma jet was applied to two entomopathogenic fungal species, and the results showed that it has the potential to be developed as an antifungal device. In a previous study exploring the killing mechanism of fungal spores by plasma treatment, it was demonstrated that plasma has a direct impact on the fungal cell wall and cellular components such as nucleolus DNA [19-22]. Generally, NTAPPJ could generate reactive oxygen and nitrogen species (RONS). When interacting with an aqua medium, NTAPPJ can produce additional reactive species by reactions between plasma radicals and water molecules, which could also be detrimental to fungal spores. NTAPPJ-treated water is known simply as plasma-activated water (PAW). The inactivation efficacy of PAW on fungal spores and biofilms was recently reported in Aspergillus flavus, a food contaminant [23]. However, how the PAW contributes to the damage of fungal spores, especially dark melanized and environmentally resistant spores, is not clear. Understanding of the mechanism of fungal spore inactivation by PAW is of great interest because PAW makes it possible to kill fungi in a relatively large volume that cannot be achieved by plasma jet.

This study was performed to clarify the influence of PAW on the viability and cell wall integrity of melanized fungal spores. For this purpose, we selected Aspergillus brasiliensis (formerly A. niger), a fungal species that produces tremendous amounts of melanin pigmented spores within short time periods and is present in the air and our living environment [24]. A. brasiliensis is a member of the black aspergilla including A. aculeatus, A. carbonarius, and A. niger. It is used in industry, in particular for enzyme production. However, it has also been associated with human asthma, ear and nose infections, and invasive pulmonary aspergillosis, especially in immunosuppressed individuals [25]. To achieve the aim of this study, we first investigated the properties of PAW generated by soft plasma jet, examined the effect of PAW treatment on the viability of $A$. brasiliensis spores, and then compared the effect on spore viability with the effect of chemically-induced $\mathrm{RONS}\left(\mathrm{H}_{2} \mathrm{O}_{2}\right.$ and $\left.\mathrm{HNO}_{3}\right)$.

\section{Materials and Experimental Methods}

\subsection{Fungal Growth and Spore Preparation}

Aspergillus brasiliensis (ATCC ${ }^{\circledR} 9642^{\mathrm{TM}}$ ) was inoculated on a medium of potato dextrose agar (PDA; Difco Laboratories, Detroit, MI, USA) and incubated for 2 weeks at $25^{\circ} \mathrm{C}$ under dark conditions to generate a sufficient number of anamorphic spores (conidia). The mycelia and spores of $A$. brasiliensis formed on the PDA medium were scraped using a sterile No. 21 blade and placed in a $50 \mathrm{~mL}$ sterile conical tube. Sterile water $(20 \mathrm{~mL})$ was added to the $50 \mathrm{~mL}$ tube and vortexed for $5 \mathrm{~min}$ to disperse the spores. A spore suspension was obtained by filtering the sterile water containing mycelia and spores through two layers of sterile gauze. A Watman filter paper No. 2 (Advantec, Toyo, Kaisha, Japan) was folded and placed in a sterile conical tube, and the gauze-filtered spore suspension was filtered 
again to remove the tiny debris of mycelia that remained in the spore suspension. During preparation, the spore suspension became black and opaque by the substances from the fungal mycelial pigment and the fungus growing medium. To confirm fungal spores without the inclusion of other components, the spore suspension was centrifuged at 8000 RPM for $5 \mathrm{~min}$ and the colored supernatant was removed. The precipitated spores were resuspended in $20 \mathrm{~mL}$ of sterile water or PAW. The presence of pure spores in the suspension was confirmed using an optical microscope and the concentration of spores was counted using a hemocytometer (Sigma-Aldrich, Bright-Line ${ }^{\mathrm{TM}}$, St. Louis, MO, USA). The final concentration of spores in water or PAW was adjusted to $5 \times 10^{7}$ spores $/ \mathrm{mL}$ and used for analysis.

\subsection{Soft Plasma Jet Device, Plasma-Activated Water Treatments, and Spore Viability}

A nonthermal atmospheric pressure air plasma jet (simply called a soft plasma jet) device consists of a power supply, a powered needle electrode, a quartz tube, and a grounded tube electrode. The quartz tube served as a dielectric barrier between the electrodes to induce an electrical discharge. Plasma radicals were generated by electrodes separated by a dielectric barrier. Electric power for the plasma device was supplied by an inverter that converts DC input to a $67 \mathrm{kHz}$ AC output. A detailed description of the soft plasma jet system was presented in a previous paper [22]. The optical emission spectrum of the soft plasma jet exhibited emission lines corresponding to $\mathrm{N}_{2}$, atomic nitrogen, atomic oxygen, and hydroxyl radicals, as reported previously [22]. The electrical signal supplied to the soft plasma jet device showed a peak voltage of $1.24 \mathrm{kV}$ (rms voltage $0.54 \mathrm{kV}$ ) and a peak current of $2.96 \mathrm{~A}$ (rms current, $97 \mathrm{~mA})$. The period of the applied voltage/current was $12 \mu \mathrm{s}$, and the duty ratio of pulse-on and pulse-off times was $18.4 \%$. The soft plasma jet could transfer $3.9 \mathrm{~J}$ per second to the sample. To find the level of RONS in the PAW generated by the soft plasma jet, $\mathrm{H}_{2} \mathrm{O}_{2}$ and $\mathrm{NO}_{x}$ concentrations in the PAW were investigated for the plasma activation times of $1,3,6$, and $10 \mathrm{~min}$.

To study the influence of PAW treatment on A. brasiliensis spores, PAW was prepared by activating sterile de-ionized (DI) water with a soft plasma jet. DI water $(3 \mathrm{~mL})$ was dispensed into each well of six-well culture plates (SPL Life Science Co., Pocheon-si, Gyeonggi-do, Korea). The water in each well was activated by the soft plasma jet for $1 \mathrm{~min}, 3 \mathrm{~min}$, and $6 \mathrm{~min}$, and was coded as PAW-1, PAW-3, and PAW-6, respectively. Because the level of RONS in the PAW is saturated for plasma activation times longer than $6 \mathrm{~min}$, the effects of PAW treatment on the viability of $A$. brasiliensis spores were examined using PAW-1, PAW-3, and PAW-6. The PAW treatment against fungal spores was performed right after the generation of the PAW. For the PAW treatment, the prepared spores were suspended in the PAW in the well of each plate at a concentration of $5 \times 10^{7}$ spores $/ \mathrm{mL}$, and incubated at room temperature for $30 \mathrm{~min}$. After PAW treatment, the viability of PAW-treated spores was measured with the PAW-untreated spores as the control.

To examine the effect of specific reactive species on the A. brasiliensis spores, $\mathrm{H}_{2} \mathrm{O}_{2}$ and $\mathrm{HNO}_{3}$ solutions were prepared in five different concentrations $(0.001 \%, 0.01 \%, 0.1 \%, 0.3 \%$, and $1.0 \%$ ). The fungal spores were treated for 30 min with each concentration of $\mathrm{H}_{2} \mathrm{O}_{2}$ and $\mathrm{HNO}_{3}$ solutions as with the PAW treatment. To measure spore viability, all the spores treated with the PAW, plasma, and $\mathrm{H}_{2} \mathrm{O}_{2}$ and $\mathrm{HNO}_{3}$ solutions were diluted with sterile water up to 10-fold, spread on PDA media, and kept at $25^{\circ} \mathrm{C}$ for 7 days, which is long enough to observe visible mycelia of fungal colonies from the survived spores. The live fungal colonies were counted and the number of colony-forming units (CFUs) was calculated to measure viability.

\subsection{Morphology and Cell Wall Structure Analysis of A. brasiliensis Spores Treated with Plasma-Activated Water}

The PAW-treated A. brasiliensis spores were subjected to flow cytometry measurements and scanning electron microscope (SEM) imaging analysis to investigate the effects of PAW treatment on the structure, integrity, and morphology of the cell wall. Field emission SEM (Hitachi, S-4300, Tokyo, Japan) was operated according to the protocol of Yun et al. [26] to examine microstructures of the PAW-treated spores, as reported previously [22]. For morphological analysis, more than 200 individual spores of each treatment were observed at different magnifications. To investigate the damage of the cell wall by 
the PAW treatment, flow cytometric assessment of the PAW-treated spores was performed according to the standard flow cytometry protocols of R\&D systems. The PAW-treated A. brasiliensis spores were stained with a membrane-impermeable fluorophore, propidium iodide (PI). Fluorescence enhancement by damaged cell walls was measured by fluorescence-activated cell sorting (FACS), as reported previously [22]. At least 10,000 events were detected in each experiment. Flow cytometric data analysis of PI-stained spores was performed with FACSuite ${ }^{\mathrm{TM}}$ software (BD FACSVerse, BD Biosciences, San Jose, CA, USA).

\subsection{Optical Spectroscopic Analyses of the PAW and A. brasiliensis Spores}

To analyze plasma-generated reactive species in the PAW, the absorption spectra of the PAW were compared with those of nitrite and nitrate ions dissolved in the aqueous solution. The nitrite and nitrate reference solutions were prepared by dissolving $\mathrm{NaNO}_{2}$ and $\mathrm{NaNO}_{3}$ in DI water, respectively. To find the absorption spectrum of nitrite (nitrate) ions dissolved in the aqueous solution, $100 \mu \mathrm{M}$ and $300 \mu \mathrm{M}$ $\mathrm{NaNO}_{2}\left(\mathrm{NaNO}_{3}\right)$ solutions were used. Absorption spectra were measured using a spectrophotometer (Jasco, J-815, Tokyo, Japan). After spores were treated with PAW for $30 \mathrm{~min}$, the PAW was replaced with fresh DI water, and then the aqueous spore solution was used in optical spectroscopic measurements.

\subsection{Electrophoretic Analysis of Genomic DNA of the A. brasiliensis Spores Treated with the Plasma-Activated Water}

Genomic DNA of $A$. brasiliensis spores was extracted by mechanically breaking the cell wall using Tissue Lyser LT (Qiagen Co., Hilden, Germany). Bead beating of the fungal spores was performed for $5 \mathrm{~min}$ with $0.1 \mathrm{~g}$ of glass beads and $400 \mu \mathrm{L}$ of breaking buffer in a $2 \mathrm{~mL}$ plastic tube. The bead-beater-ruptured spores were treated with phenol-chloroform to extract DNA [27]. After centrifugation at 13,200 RPM for $10 \mathrm{~min}$, the top layer aliquot $(300 \mu \mathrm{L})$ was taken, mixed with $1 \mathrm{~mL}$ of $100 \%$ ethanol and $130 \mu \mathrm{L}$ of sodium acetate in a $2 \mathrm{~mL}$ plastic tube, and stored at $-80^{\circ} \mathrm{C}$ for $20 \mathrm{~min}$. The stored plastic tube was centrifuged again as before at $4{ }^{\circ} \mathrm{C}$. The supernatant was removed and the DNA precipitate in the bottom of the plastic tube was cleaned twice using $1 \mathrm{~mL}$ of $70 \%$ ethanol by centrifugation at $13,200 \mathrm{RPM}$ at $4{ }^{\circ} \mathrm{C}$ for $5 \mathrm{~min}$. To remove any traces of ethanol, the washed DNA was dried using a $37^{\circ} \mathrm{C}$ heating block and dissolved in $20 \mu \mathrm{L}$ of elution buffer. A $1 \%$ agarose gel electrophoresis was run with the dissolved DNA as described in a previous study [22].

\section{Results and Discussion}

\subsection{Characteristics of the Plasma-Activated Water Produced by the Soft Plasma Jet}

In this research, a nonthermal atmospheric pressure air plasma jet (soft plasma jet) was used to prepare PAW for treating A. brasiliensis spores. The soft plasma jet exhibited typical output characteristics of a nonthermal atmospheric pressure plasma jet, as reported previously [22]. Because oxygen molecules could receive sufficient amounts of electrons by the plasma, they could be transformed to reactive oxygen intermediates $\left(\mathrm{OH}, \mathrm{O}_{2}^{-}\right.$and $\left.\mathrm{H}_{2} \mathrm{O}_{2}\right)$ through the $\mathrm{O}_{2}$-reduction pathway: $\mathrm{O}_{2} \rightarrow \mathrm{O}_{2}^{-} \rightarrow \mathrm{H}_{2} \mathrm{O}_{2} \rightarrow \mathrm{OH} \rightarrow \mathrm{H}_{2} \mathrm{O}[28,29]$. When the soft plasma jet entered the aqueous solution, additional RONS could be induced from the interaction between plasma radicals and water molecules, presented in the following reactions [30-38]:

$$
\begin{gathered}
\mathrm{N}_{2}+e \rightarrow \mathrm{N}+\mathrm{N}+e \\
\mathrm{O}_{2}+e_{a q} \rightarrow \mathrm{O}_{2}^{-}, \\
2 \mathrm{H}_{2} \mathrm{O}+\mathrm{M}^{+} \rightarrow \mathrm{H}^{+}\left(\mathrm{H}_{2} \mathrm{O}\right)+\mathrm{OH}+\mathrm{M}, \\
\mathrm{N}+\mathrm{O}_{2} \rightarrow \mathrm{NO}+\mathrm{O} \\
\mathrm{NO}+\mathrm{O}_{2}^{-} \rightarrow \mathrm{ONOO}^{-}
\end{gathered}
$$




$$
\begin{gathered}
\mathrm{NO}+\mathrm{HO}_{2} \rightarrow \mathrm{ONOOH} \\
4 \mathrm{NO}+\mathrm{O}_{2}+2 \mathrm{H}_{2} \mathrm{O} \rightarrow 4 \mathrm{NO}_{2}^{-}+4 \mathrm{H}^{+}, \\
3 \mathrm{NO}_{2}^{-}+3 \mathrm{H}^{+} \rightarrow 2 \mathrm{NO}+\mathrm{NO}_{3}^{-}+\mathrm{H}^{+}\left(\mathrm{H}_{2} \mathrm{O}\right) .
\end{gathered}
$$

where $e$ and $e_{a q}$ are dry (non-hydrated) and wet (hydrated) electrons, respectively, $M^{+}$is any plasma ion with ionization energy above the $\mathrm{H}_{2} \mathrm{O}$ ionization threshold, and $\mathrm{H}^{+}\left(\mathrm{H}_{2} \mathrm{O}\right)$ represents the hydrated hydrogen ion. $\mathrm{O}_{2}^{-}$and $\mathrm{HO}_{2}$ are converted to stable end products $\left(\mathrm{H}_{2} \mathrm{O}_{2}\right)[39,40]$.

$$
\begin{gathered}
\mathrm{HO}_{2}+\mathrm{HO}_{2} \rightarrow \mathrm{H}_{2} \mathrm{O}_{2}+\mathrm{O}_{2}, \\
\mathrm{HO}_{2}+\mathrm{O}_{2}^{-}+\mathrm{H}_{2} \mathrm{O} \rightarrow \mathrm{H}_{2} \mathrm{O}_{2}+\mathrm{O}_{2}+\mathrm{OH}^{-} .
\end{gathered}
$$

$\mathrm{O}_{2}^{-}, \mathrm{NO}_{2}^{-}$, and $\mathrm{NO}_{3}^{-}$anions exist in equilibrium with their conjugate acids $\left(\mathrm{HO}_{2}, \mathrm{HNO}_{2}\right.$, and $\left.\mathrm{HNO}_{3}\right)$, respectively [39].

$$
\begin{gathered}
\mathrm{O}_{2}^{-}+\mathrm{H}^{+} \rightleftarrows \mathrm{HO}_{2}, p K_{a}=4.8 \\
\mathrm{NO}_{2}^{-}+\mathrm{H}^{+} \rightleftarrows \mathrm{HNO}_{2}, p K_{a}=3.3 \\
\mathrm{NO}_{3}^{-}+\mathrm{H}^{+} \rightleftarrows \mathrm{HNO}_{3}, p K_{a}=-1.4
\end{gathered}
$$

The concentrations of $\mathrm{NO}_{2}^{-}, \mathrm{HNO}_{2}, \mathrm{NO}_{3}^{-}, \mathrm{HNO}_{3}, \mathrm{O}_{2}^{-}$, and $\mathrm{HO}_{2}$ in the PAW depend on the acidity of the PAW [39]. When DI water was activated for 1, 3, 6, and $10 \mathrm{~min}$ by the soft plasma jet, the $\mathrm{pH}$ values of PAW (1 min), PAW (3 min), PAW (6 min), and PAW (10 min) were 3.53, 3.24, 3.10, and 3.01, respectively. This indicates that the acidity of PAW becomes stronger with the increase of plasma activation time. Meanwhile, $\mathrm{NO}$ can react with $\mathrm{O}_{2}^{-}$or $\mathrm{HO}_{2}$ or oxygenated aqueous solution, generating peroxynitrite $\left(\mathrm{ONOO}^{-}\right)$or peroxynitrous acid $(\mathrm{ONOOH})$ or nitrous acid $\left(\mathrm{HNO}_{2}\right)$. As with oxidative stress by reactive oxygen species [41,42], these reactive nitrogen species could also react with the biological components of cells [43]. Among the reactive species derived from the interaction of plasma radicals with an aqueous solution, hydrogen peroxide $\left(\mathrm{H}_{2} \mathrm{O}_{2}\right)$ and nitric acid $\left(\mathrm{HNO}_{3}\right)$ are more stable when compared to free radicals such as $\mathrm{OH}, \mathrm{O}_{2}^{-}, \mathrm{NO}$, etc.

Experimentally, the concentrations of $\mathrm{H}_{2} \mathrm{O}_{2}$ in the PAW were measured using a QuantiChrom ${ }^{\mathrm{TM}}$ Peroxide Assay Kit (DIOX-250). When DI water was activated for $3 \mathrm{~min}$ by the soft plasma jet, the concentration of $\mathrm{H}_{2} \mathrm{O}_{2}$ in the PAW was measured to be $50 \mu \mathrm{M}$. This confirms that reactive oxygen species are present in the PAW. The concentration of plasma-induced $\mathrm{H}_{2} \mathrm{O}_{2}$ increased with longer plasma activation time, as shown in Figure 1a. Next, the concentrations of $\mathrm{NO}_{x}\left(\mathrm{NO}_{2}^{-}\right.$and $\left.\mathrm{NO}_{3}^{-}\right)$in the PAW were measured using a QuantiChrom ${ }^{\mathrm{TM}}$ Nitric Oxide Assay Kit (DIOX-100). The concentration of $N O_{x}$ in the PAW with a plasma activation time of $3 \mathrm{~min}$ was measured to be $1.8 \mathrm{mM}$. The plasma-induced $N O_{x}$ concentration also increased with longer plasma activation time, as shown in Figure 1b. Los et al. reported that the concentrations of $\mathrm{H}_{2} \mathrm{O}_{2}$ and nitrate in PAW treated for $5 \mathrm{~min}$ by DBD plasma with plane-parallel electrodes were measured to be $114.04 \mu \mathrm{M}$ (indirect) $/ 403.84 \mu \mathrm{M}$ (direct) and $150.0 \mu \mathrm{M}$ (indirect)/1.14 mM (direct), respectively [23]. The PAW was prepared by treating DI water with a DBD plasma device that consisted of two circular aluminum plate electrodes (158 mm diameter) over polypropylene dielectric layers ( $2 \mathrm{~mm}$ thickness). In this work, the PAW was prepared by activating DI water with an electric shock-free, nonthermal atmospheric pressure air plasma jet. The level of RONS in the PAW generated by the soft plasma jet are comparable to those generated by the DBD plasma. 


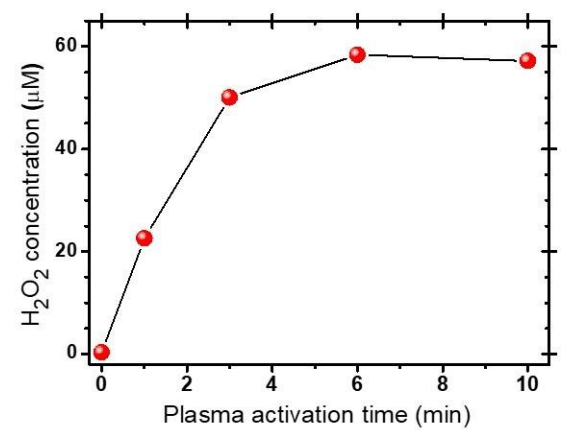

(a)

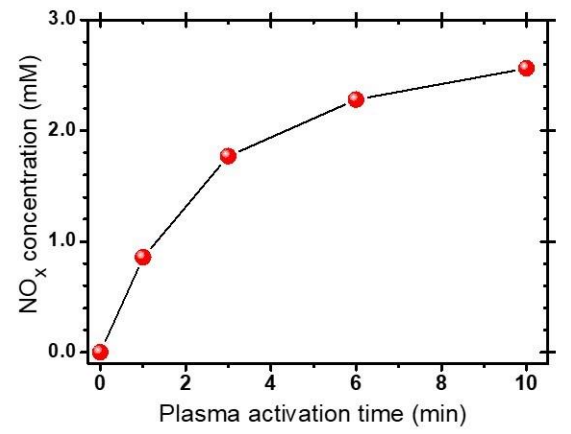

(b)

Figure 1. (a) $\mathrm{H}_{2} \mathrm{O}_{2}$ and (b) $\mathrm{NO}_{x}$ concentrations of the plasma-activated water (PAW) as a function of plasma activation time. The PAW was prepared by activating de-ionized (DI) water with the soft plasma jet.

To further investigate the plasma-induced reactive nitrogen species, the optical absorption spectra of the PAW were measured. As shown in Figure 2a,b, the nitrite and nitrate reference solutions exhibited absorption peaks at 209.2 and $200.8 \mathrm{~nm}$, respectively. The PAW exhibited an absorption peak at $205.5 \mathrm{~nm}$, indicating that both nitrite and nitrate ions coexist in the PAW. Figure 3 exhibits the absorption spectra of the PAW in the wavelength region of 300-420 nm. For all the plasma activation times of 1, 3, 6, and $10 \mathrm{~min}$, the absorption spectra of the PAW in Figure 3a exhibit four absorption peaks at $346.8,358.1,371.0$, and $386.0 \mathrm{~nm}$, respectively, attributable to the $n-\pi^{*}$ electronic transition of aqueous $\mathrm{NO}_{2}^{-}$and $\mathrm{HNO}_{2}$. Meanwhile, the nitrite reference solutions exhibit a single absorption peak at $347 \mathrm{~nm}$, as shown in Figure 3b. This result indicates that the PAW contains $\mathrm{HNO}_{2}$ as well as $\mathrm{NO}_{2}^{-}$. On comparing the measured absorption spectrum of the PAW with the molar absorption coefficients of $\mathrm{HNO}_{2}, \mathrm{NO}_{2}^{-}$, and $\mathrm{NO}_{3}^{-}$, which are described in the literature [44-47], the concentrations of $\mathrm{HNO}_{2}, \mathrm{NO}_{2}^{-}$, and $\mathrm{NO}_{3}^{-}$in the PAW were estimated to be $0.59 \mathrm{mM}, 0.72 \mathrm{mM}$, and $1.04 \mathrm{mM}$, respectively. When $\mathrm{NO}_{x}$ was approximated as the sum of $\mathrm{HNO}_{2}, \mathrm{NO}_{2}^{-}$, and $\mathrm{NO}_{3}^{-}$, the concentration of $\mathrm{NO}_{x}$ measured by optical absorption spectra of the PAW in $300-420 \mathrm{~nm}$ was $2.3 \mathrm{mM}$. This concentration is comparable to that measured by a Nitric Oxide Assay Kit (DIOX-100). Under acidic conditions, the formation of conjugate acids $\left(\mathrm{HO}_{2}, \mathrm{HNO}_{2}\right.$, and $\left.\mathrm{HNO}_{3}\right)$ corresponding to $\mathrm{O}_{2}^{-}, \mathrm{NO}_{2}^{-}$, and $\mathrm{NO}_{3}^{-}$could play an important role in the inactivation of fungal spores. These results demonstrate that the PAW produced by our soft plasma jet device contains RONS that react readily with cellular components such as lipids, proteins, carbohydrates, and nucleic acids and may result in significant damage to cell structures, cumulating in a condition known as oxidative stress [42,48].

\subsection{Viability of the A. brasiliensis Spores Treated with Plasma-Activated Water and Chemically Induced RONS Solutions}

Both the PAW and the direct plasma treatments against $A$. brasiliensis spores revealed that they have a remarkable effect on the viability of the spores, as seen in Figure 4a. The PAW treatment clearly reduced spore viability. A reduction of the spore viability tended to increase with the treatments of PAW that had longer plasma activation times. After being treated for $30 \mathrm{~min}$ in the PAW with a plasma activation time of $3 \mathrm{~min}$, the spore viability dropped sharply to $15 \%$, indicating that the PAW treatment significantly inactivated $85 \%$ of the tested spores. The spore viability also quickly dropped to $9 \%$ when the spores were treated directly with the soft plasma jet for $3 \mathrm{~min}$. This result indicates that the viability of the PAW-treated spores is almost comparable to that of the spores treated directly with plasma. These results demonstrated that the PAW produced by the soft plasma jet can be applied in fungal spore inactivation. Since $\mathrm{H}_{2} \mathrm{O}_{2}$ and $\mathrm{HNO}_{3}$ were stable and long-lived reactive species and were confirmed to be present in the PAW (Figures 1-3), they were considered to be key agents for fungal spore inactivation. To provide evidence that they can work against black pigment-protected 
spores, we investigated the effect of $\mathrm{H}_{2} \mathrm{O}_{2}$ and $\mathrm{HNO}_{3}$ solutions on the spores. For this investigation, A. brasiliensis spores were treated with either $\mathrm{H}_{2} \mathrm{O}_{2}$ or $\mathrm{HNO}_{3}$ solutions with $0.001 \%, 0.01 \%, 0.1 \%, 0.3 \%$, and $1.0 \%$ concentrations. As shown in Figure $4 \mathrm{~b}$, both $\mathrm{H}_{2} \mathrm{O}_{2}$ and $\mathrm{HNO}_{3}$ treatments reduced spore viability in a concentration-dependent manner. These results demonstrate that $\mathrm{H}_{2} \mathrm{O}_{2}$ and $\mathrm{HNO}_{3}$ are key players in fungal spore inactivation. Therefore, we could deduce that plasma-induced $\mathrm{H}_{2} \mathrm{O}_{2}$ and $\mathrm{HNO}_{3}$ could lead to irreversible intracellular damage in $\mathrm{A}$. brasiliensis spores. These results agreed with those on the effect of PAW treatment on Aspergillus flavus spores [23]. However, Los et al. treated the A. flavus spores using PAW generated by an electric discharge between plane-parallel electrodes and investigated the effect of PAW treatment on A. flavus spores with a plasma activation time of $5 \mathrm{~min}$ and a PAW treatment time of $24 \mathrm{~h}$. Their plasma device and treatment parameters are different from those of our study, which used a plasma activation time of $3 \mathrm{~min}$ and a contact time of $30 \mathrm{~min}$ for treating A. brasiliensis spores. Meanwhile, we treated A. brasiliensis spores using PAW generated by an electric shock-free, nonthermal atmospheric pressure air plasma jet. The coaxial electrodes plasma jet can generate high density radicals in a relatively large volume by activating DI water with the plasma jet, but plane-parallel electrodes plasma can activate water between electrodes. In addition, plane-parallel electrodes plasma requires relatively high voltage as compared with plasma jet with coaxial electrodes. When considering plasma treatment effects, it seems that our system is more efficient. However, A. flavus is a different species. Thus, there is the possibility that this different inactivation efficiency could also be due to the different biological properties of the two species. To clarify the discrepancy, a comparative study with the same plasma device will be necessary.

Generally, nonenzymatic antioxidants such as carotenoids, polysaccharides, chitosan, polyphenol, polyols, mannitol, glucose, and vitamins in fungi have oxygen radical scavenging effects [49-52]. It was well known that glucose and mannose exist in the cell wall of $A$. brasiliensis spores [53]. The filamentous fungus $A$. niger produces several different polyols, including glycerol, erythritol, and D-mannitol [54]. In A. niger spores, D-mannitol is the predominant carbon-containing compound and makes up $10-15 \%$ of the dry weight [54]. Physiological functions of mannitol include serving as a reserve carbon source and as an antioxidant to store reducing power. Molecular genetic analysis of $m p d A$, the gene encoding the first enzyme in the mannitol biosynthesis pathway, revealed that spores of the $A$. niger mutant strain with a deficiency in $m p d A$ were extremely sensitive to a variety of stress conditions, including oxidative stress [55]. Furthermore, the $m p d A$ mutant study indicated that there is no evidence for the role of mannitol as a reserve carbon source in conidia, but mannitol is essential for resistance to a variety of stress conditions. Since certain strains of $A$. niger were reclassified into $A$. brasiliensis, we need to confirm whether mannitol is present in A. brasiliensis spores [24]. Darkly pigmented A. brasiliensis spores were subjected to cell component analysis using high-performance liquid chromatography (HPLC). We confirmed with HPLC analysis that mannitol and glucose exist in A. brasiliensis spores (Figure 5). There were two other peaks in the HPLC chromatogram that are not matched with known standard materials. The materials of the two unassigned peaks need to be analyzed with further study. When we consider oxygen radical scavenging properties of mannitol and glucose, we could not rule out that these compounds in $A$. brasiliensis spores are expected to scavenge $\mathrm{H}_{2} \mathrm{O}_{2}$ and $\mathrm{NO}_{x}$ in PAW. PAW-1 treatment for $30 \mathrm{~min}$ did not show notable effects on spore viability. In this case, mannitol and glucose might function as scavengers of RONS in A. brasiliensis spores. Meanwhile, PAW-3 or PAW-6 treatment for $30 \mathrm{~min}$ reduced the spore viability of $A$. brasiliensis. In this case, it could be possible that the radical scavenging capacity of mannitol and glucose is not enough to deter a reduction in spore viability. The viability of $0.3 \% \mathrm{H}_{2} \mathrm{O}_{2}$-treated spores was $22 \%$, but the viability of $0.3 \% \mathrm{HNO}_{3}$-treated spores was $42 \%$. Spore viability decreased with an increase of $\mathrm{H}_{2} \mathrm{O}_{2}$ and $\mathrm{NO}_{x}$ concentrations, as shown in the Figure $4 \mathrm{~b}$. Between these reactive species, the spore inactivation effect was higher with $\mathrm{H}_{2} \mathrm{O}_{2}$ treatment [40]. Since both $\mathrm{H}_{2} \mathrm{O}_{2}$ and $\mathrm{NO}_{x}$ can induce the modifications of intracellular components such as nucleic acids and proteins $[40,43]$ that lead to a detrimental effect on cell viability, a reduction of the spore viability by $\mathrm{H}_{2} \mathrm{O}_{2}$ and $\mathrm{HNO}_{3}$ treatments suggests that $\mathrm{H}_{2} \mathrm{O}_{2}$ and $\mathrm{NO}_{x}$ are key factors deciding fungal spore inactivation. The fungicidal effects of the PAW due to plasma-induced $\mathrm{H}_{2} \mathrm{O}_{2}$ 
and $\mathrm{NO}_{x}$ could be supported by the data of Figure 1: The concentrations of $\mathrm{H}_{2} \mathrm{O}_{2}$ and $\mathrm{NO}_{x}$ increase with longer plasma activation times. That is, PAW-3 and PAW-6 contain sufficient amounts of $\mathrm{H}_{2} \mathrm{O}_{2}$ and $N O_{x}$ to inactivate $A$. brasiliensis spores.

(a)

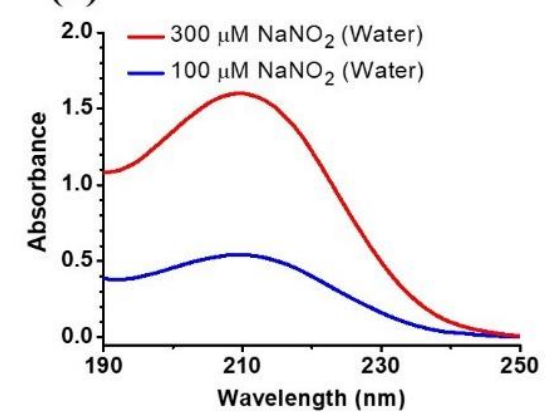

(c)

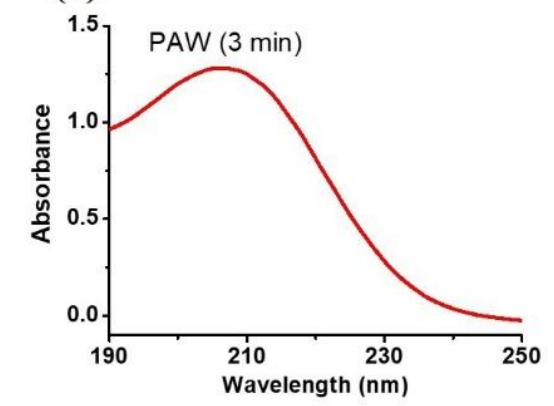

(b)

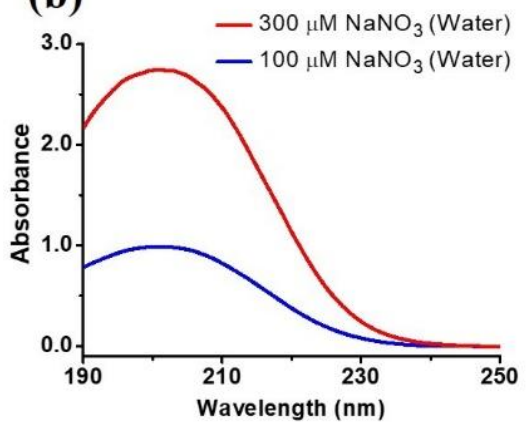

- 1, $100 \mu \mathrm{M} \mathrm{NaNO}$ (water)

(d) -2, $100 \mu \mathrm{M} \mathrm{NaNO}$ (water)

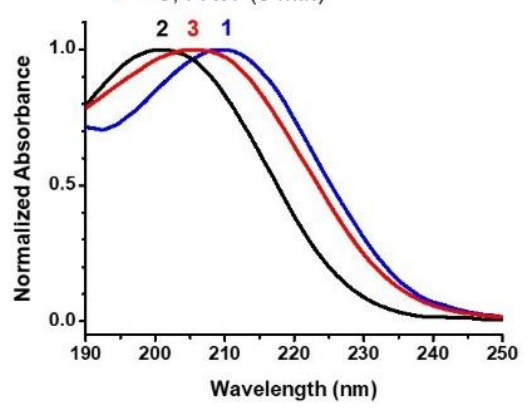

Figure 2. Optical absorption spectra of (a) nitrite, (b) nitrate, and (c) PAW in the wavelength region of 190-250 nm. (d) Normalized absorption spectra of nitrite, nitrate, and PAW. In (c,d), the PAW was prepared by activating DI water for 3 min with the soft plasma jet.

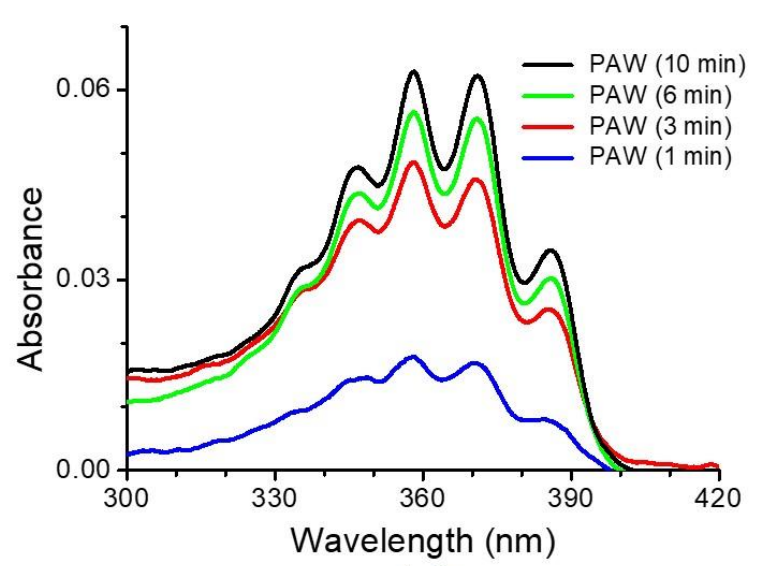

(a)

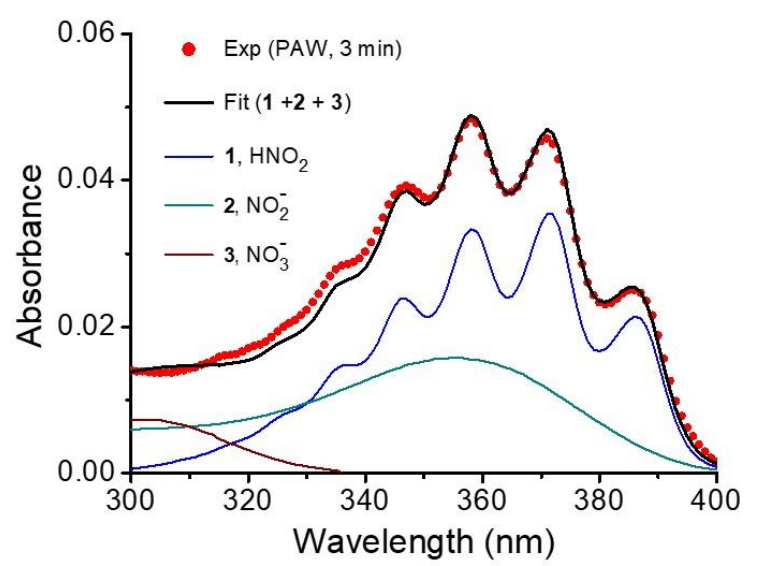

(b)

Figure 3. (a) Optical absorption spectra of the PAW in the wavelength region of 300-420 nm and (b) the fit of the experimental absorption spectrum of the PAW to the sum of three components $\left(\mathrm{HNO}_{2}, \mathrm{NO}_{2}^{-}\right.$, and $\mathrm{NO}_{3}^{-}$). The plasma-untreated water is transparent in the wavelength region of 300-420 nm. DI water was activated by the soft plasma jet for 1,3,6 and $10 \mathrm{~min}$, respectively. 

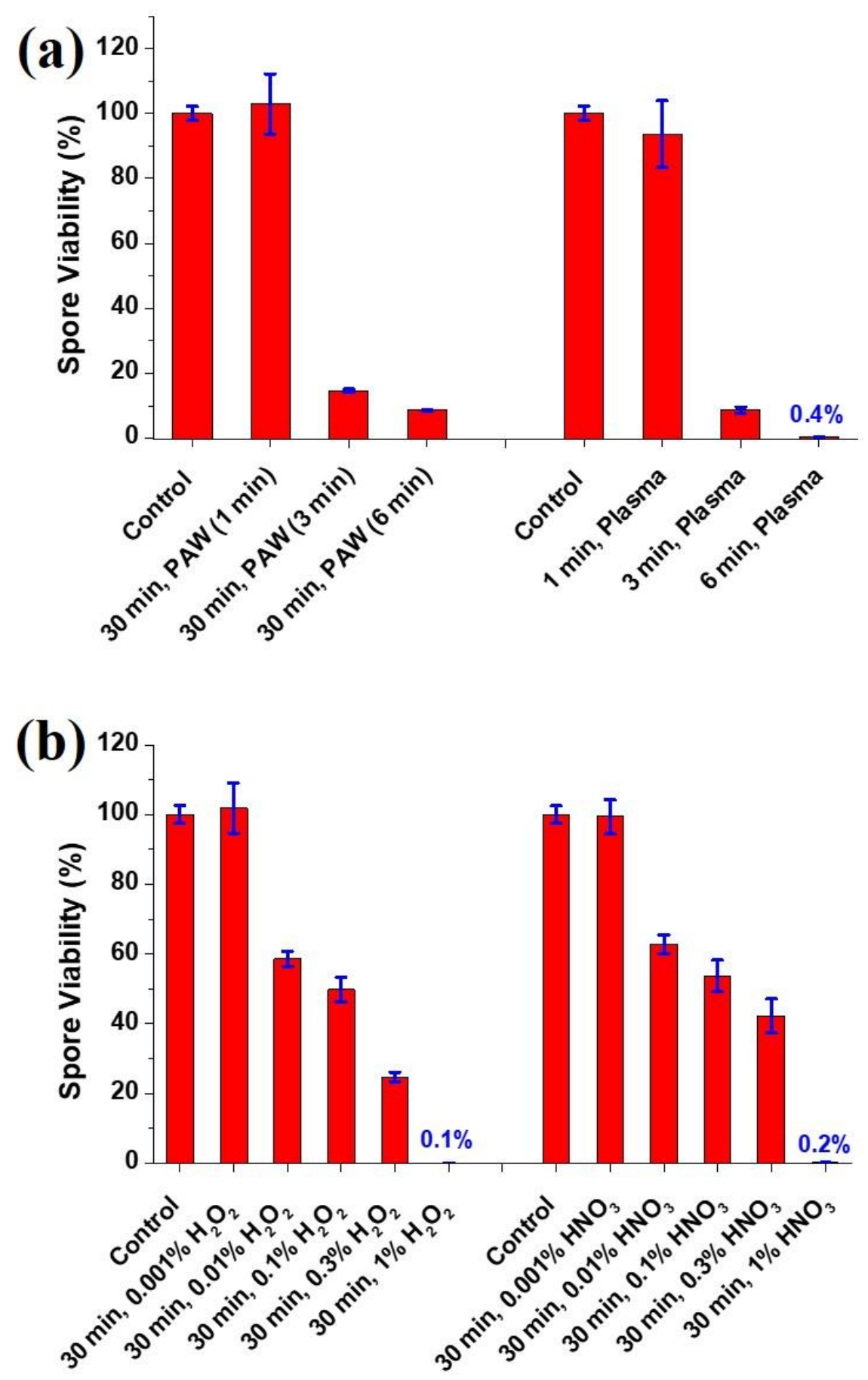

Figure 4. Viability of the A. brasiliensis spores treated by (a) the PAW and direct plasma and (b) chemically induced reactive oxygen and nitrogen species (RONS) $\left(\mathrm{H}_{2} \mathrm{O}_{2}\right.$ and $\left.\mathrm{HNO}_{2}\right)$ solutions. In (a), PAW (1 min), PAW (3 min), and PAW (6 min) are water activated by the plasma for 1, 3, and 6 min, respectively. Direct plasma treatment times are 1,3, and $6 \mathrm{~min}$. The contact time of the A. brasiliensis spores with PAW and chemically induced RONS solutions was $30 \mathrm{~min}$. 


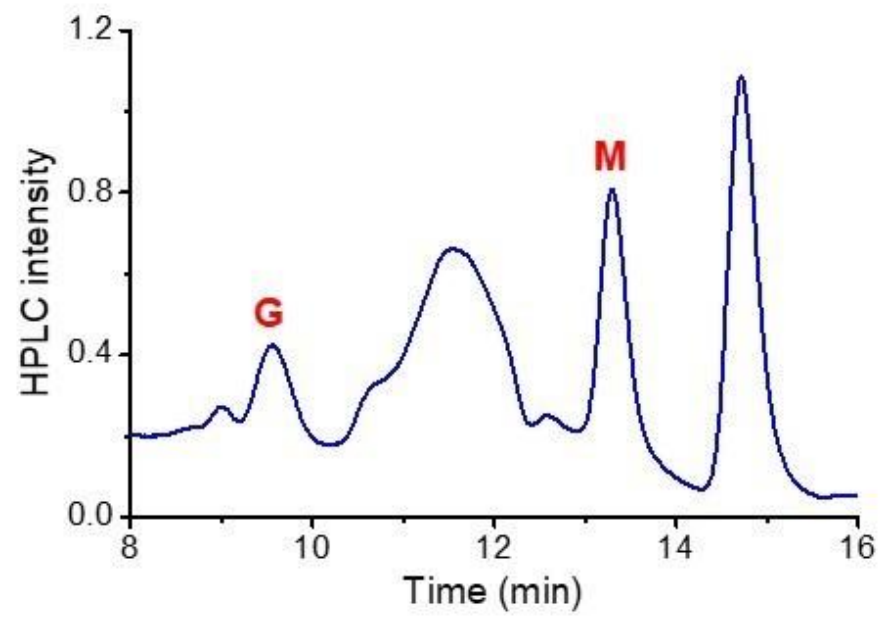

Figure 5. HPLC chromatograms of the cellular extract of the A. brasiliensis spores. G and M represent glucose and mannitol peaks.

\subsection{Morphology and Cell Wall Structure of the A. brasiliensis Spores Treated with Plasma-Activated Water}

Cell walls and cell membranes are pivotal in controlling cell survival and death in fungi. Therefore, the development of antifungal reagents has focused on finding substances that could disrupt cell walls and cell membranes or inhibit their synthesis [56]. In previous works with plasma treatment on insect pathogenic fungal spores, we found that cell morphology of the plasma-treated spores was shrunken, ruptured, and flattened, indicating it had changed considerably [21]. The effects of PAW treatment on Aspergillus fungal cells were studied first in the spores of A. flavus [23]. Los et al. showed that the PAW treatment of A. flavus spores could reduce the viability and metabolic activity of the fungus. However, their study did not observe the morphology of spore cell walls treated with PAW, and thus whether PAW is involved in the occurrence of mechanical damage remains in question. The SEM images of PAW-treated Aspergillus spores in our study are shown in Figure 6. There was a prominent change in the cell morphology of the PAW-treated spores compared with that of control spores. SEM images show that the PAW-treated A. brasiliensis spores have porous walls, which are not observed in control spores. The formation of holes on the surface of the spore cell wall was the major deformation and the size of the holes varied little among spores. Despite cell wall and membrane damage, the inner cellular components remained mostly inside the punctured spores. The PAW-treated spores did not show flattened spores. These properties contrast with the changes in spore cell wall morphology observed in direct plasma treatment. Our SEM data clearly show that the PAW treatment could cause fungal spore damage by the opening of cell walls. This result means that with direct plasma treatment, the RONS in PAW function by attacking the cell walls of the A. brasiliensis spores. The size and number of opened holes are sufficient to allow RONS in the PAW to penetrate the cell wall and membrane barriers, react with intracellular components such as nucleic acids, proteins, and other metabolites, and cause malfunctioning, resulting in spore cell death. 

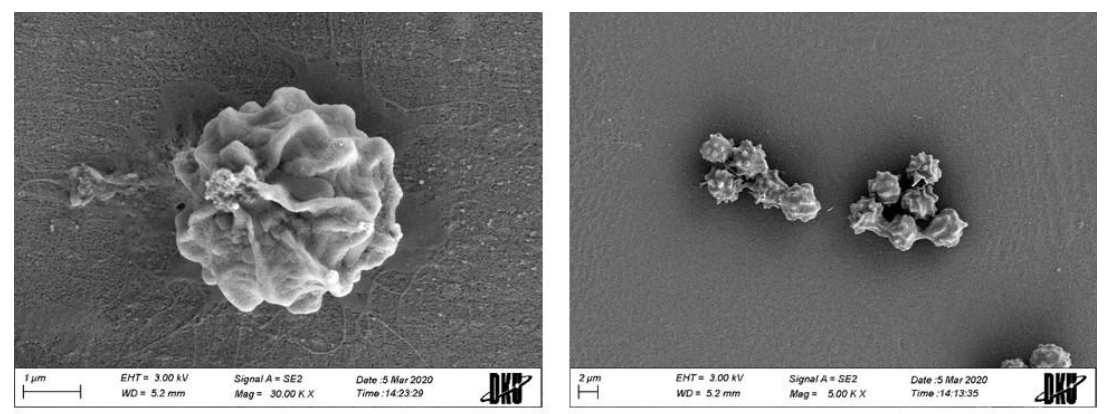

(a) PAW-untreated
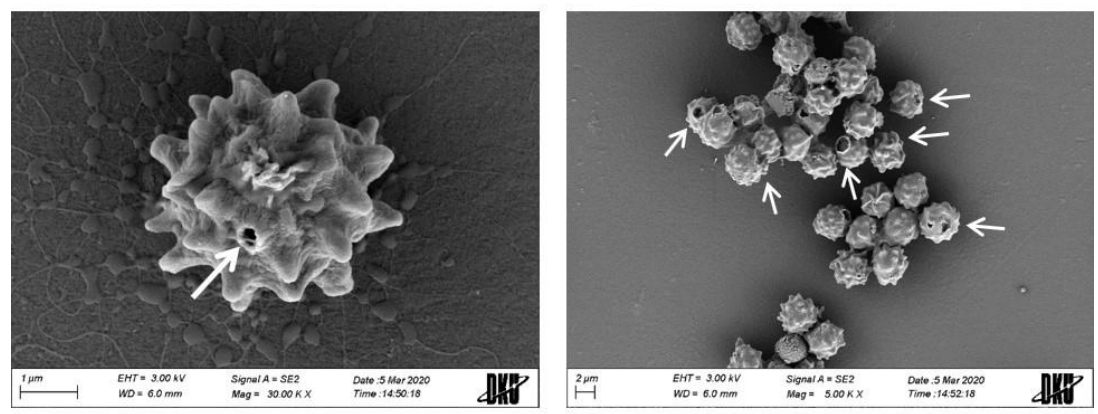

(b) PAW-treated (3 min)

Figure 6. Typical SEM images of (a) PAW-untreated and (b) PAW-treated A. brasiliensis spores. The spores were treated by the PAW for $30 \mathrm{~min}$. Arrows in the SEM image of (b) indicate the holes formed on the surface of the fungal spore cell walls.

To verify and measure the level of structural damage in the cell wall and membranes of $A$. brasiliensis spores, we stained the PAW-untreated and PAW-treated spores with PI dye. The permeability of PI dye molecules through the damaged membranes in dead cells is relatively higher than that through a normal membrane in living cells. As shown in Figure 7, the gated fluorescence intensity of PI-stained A. brasiliensis spores is more intense in the PAW-treated spores than in the PAW-untreated spores. Subpeaks are clearly shown in the PAW-treated samples at higher fluorescence intensity, which were absent in the control sample. In Figure 7b, we present the P2-gated fluorescence intensity, calculated from the flow cytometry spectra of Figure 7a. It indicates a 3-fold increase in the PAW-treated samples compared to that of the control. Enhanced fluorescence in the PAW-treated spores is attributed to the penetration of the PI dye into the intracellular region of spores through the damaged membrane. The gated fluorescence intensity was similar between PAW-3 and PAW-6 treated spores. This indicates that the PAW with a plasma activation time of $3 \mathrm{~min}$ or more has the potential to cause sufficient damage in the fungal spores. Thus, these data support the results shown in Figure 6 and indicate that PAW can disrupt the rigid cell wall structure of melanized A. brasiliensis spores. The Aspergillus cell wall is a complex structure composed of a network of polysaccharides ( $\alpha$-glucan, $\beta$-glucan, chitin, and galactomannan) and cell wall proteins. Thus, we recognize that the Aspergillus cell wall is an essential factor in maintaining the shape and integrity of the fungal cell [57]. Our study revealed that PAW induced the loss of cell wall integrity and its protective function in the spores. Because cell membranes control traffic into and out of cellular components, damaged membranes lose their control function and thus allow intracellular components such as nucleic acids, proteins, and other metabolites possibly to leak out. However, we do not know yet what cell wall components were affected by RONS in the PAW. According to the proteomic study by Guozheng et al., cellular membrane damage was not the main reason for $\mathrm{H}_{2} \mathrm{O}_{2}$-induced death of Penicillium expansum, a food spoilage fungus [58]. Their results suggest that mitochondrial impairment due to the functional alteration of 
oxidative stress-sensitive proteins is associated with fungal death caused by $\mathrm{H}_{2} \mathrm{O}_{2}$. Since we detected $\mathrm{H}_{2} \mathrm{O}_{2}$ and $\mathrm{NO}_{x}$ in PAW-3 and PAW-6, we deduced that $\mathrm{H}_{2} \mathrm{O}_{2}$ and $\mathrm{NO}_{x}$ in the PAW passed through the opened pores in the cell wall to enter the spore cells and to react with oxidative stress-sensitive intracellular components (DNA, proteins in mitochondria) and eventually bring about spore cell death. This deduction would describe one of the mechanistic processes that lead to the inactivation of fungal spores.
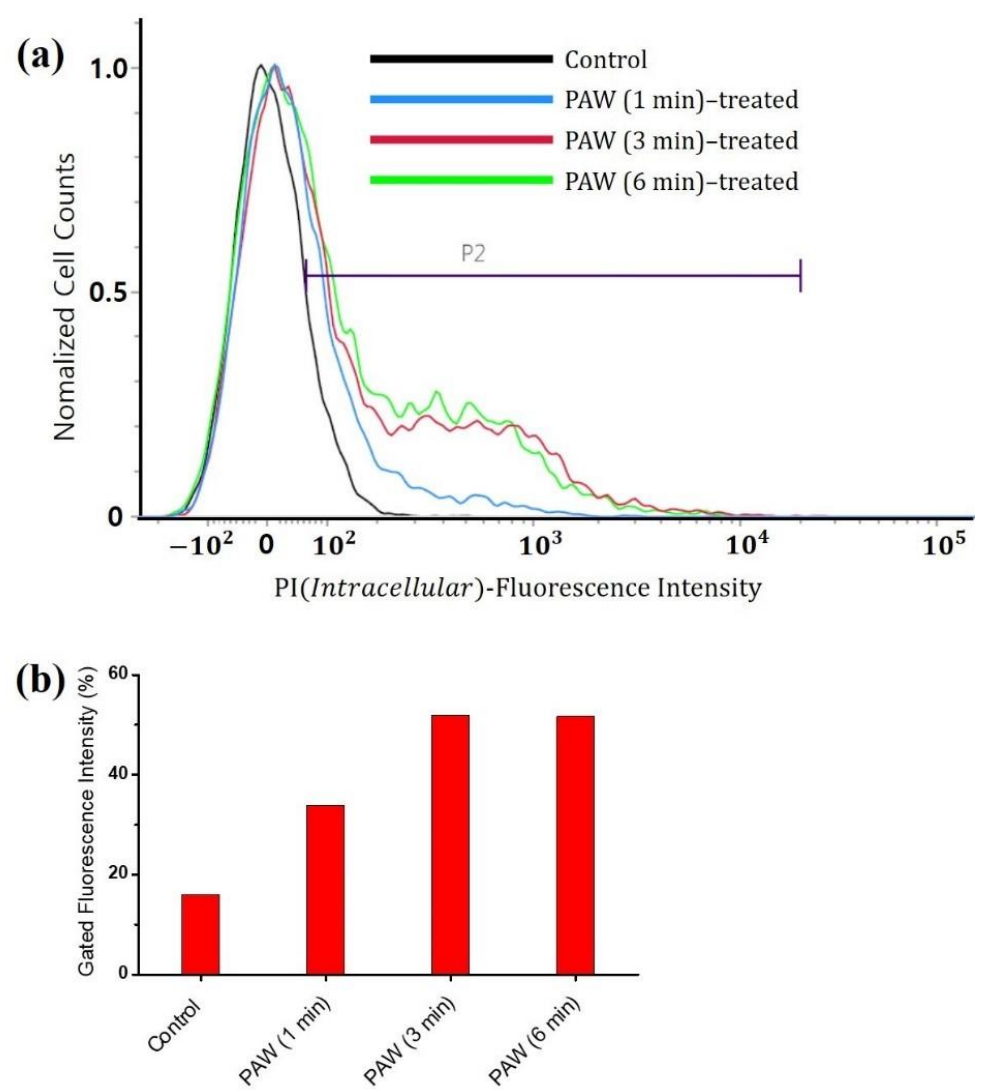

Figure 7. (a) Flow cytometry measurements of fluorescence intensity for the PAW-untreated and PAW-treated A. brasiliensis spores. (b) Gated fluorescence intensity for the PAW-untreated and PAW-treated spores. The black, blue, red, and green-colored curves represent the fluorescence intensities of the control, PAW (1 min), PAW (3 min), and PAW (6 min)-treated spores, respectively. The PAW-untreated and PAW-treated spores were stained with a membrane-impermeable fluorophore, propidium iodide (PI), to investigate the effect of PAW on cell wall integrity.

\subsection{Electrophoretic Analysis of Genomic DNA Extracted from the A. brasiliensis Spores Treated with Plasma-Activated Water}

Genomic DNA is chromosomal DNA that governs the function of cells and growth. In fungi, it is enclosed in a nucleolus with a protective membrane. Section 3.3 demonstrates that RONS can reach intracellular components such as protein, nucleic acids, etc. Thus, it is expected that RONS could react with genomic DNA and damage it. To examine whether PAW treatment leads to the degradation of genomic DNA, we extracted genomic DNA from A. brasiliensis spores with and without PAW treatment (negative control). The PAW-1, PAW-2, and PAW-6 were used for the fungal spore treatment. We also examined genomic DNA from the A. brasiliensis spores with direct plasma treatment for $3 \mathrm{~min}$ as positive control for DNA damage. The extracted DNAs were analyzed by agarose gel electrophoresis (Figure 8). The genomic DNA of the negative control showed a high molecular DNA band, and some of the DNA bands ranged from $1.5 \mathrm{~kb}$ to around $0.25 \mathrm{~kb}$, which are normal in fungal genomic DNA preparation [19]. The genomic DNA of PAW-1 treated spores showed a similar band pattern to that 
of the negative control. However, the genomic DNA from the spores treated with the PAW-3 and PAW-6 did not show the high molecular DNA band and only showed smeared DNA bands of around $0.25 \mathrm{~kb}$. This result agreed with the electrophoresis pattern of the genomic DNA of the positive control. This agarose gel analysis demonstrates that the PAW treatment with a plasma activation time of $3 \mathrm{~min}$ or more could damage the genomic DNA of the A. brasiliensis spores, and the electrophoresis pattern of the damaged genomic DNA by the PAW is similar to that by plasma jet. The genomic DNA damage of spores by the PAW-3 treatment could contribute to sharp reduction of spore viability (Figures 4a and 7). Overall, these results indicate that PAW possesses the same fungicidal ability as the plasma jet. This is the first report to demonstrate that PAW can damage the genomic DNA of fungal spores. It is reported that the oxidative damage by RONS involves DNA strand breaks and modifications of nucleobases, deoxyribose, and nucleotides [59-62]. Thus, we believe that the RONS contained in the PAW work similarly against the spore DNA of $A$. brasiliensis.

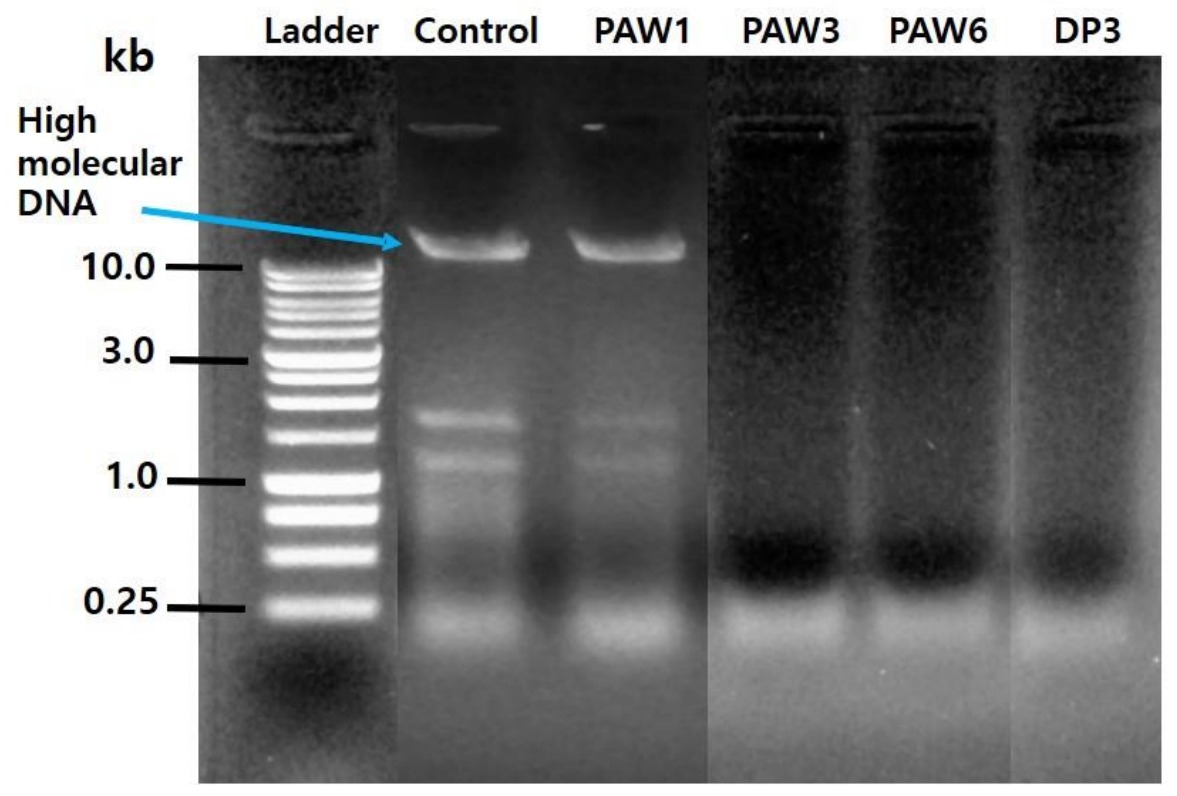

Figure 8. Electrophoretic analysis of genomic DNA from A. brasiliensis spores treated by the PAW. Lane 1 (ladder): $1 \mathrm{~kb}$ ladder DNA marker, lane 2 (Control): negative control of genomic DNA from the A. brasiliensis spores without the PAW treatment, lane 3 (PAW1): genomic DNA from the A. brasiliensis spores with PAW-1 treatment, lane 4 (PAW3): genomic DNA from the A. brasiliensis spores with PAW-3 treatment, lane 5 (PAW6): genomic DNA from the A. brasiliensis spores with PAW-6 treatment, and lane 7 (DP3): positive control of genomic DNA from the A. brasiliensis spores with direct plasma treatment for $3 \mathrm{~min}$.

\section{Conclusions}

PAW was successfully prepared by the activation of water with a soft plasma jet. The amount of plasma-induced RONS in PAW increased in a time-dependent manner. The PAW treated by the soft plasma jet for $3 \mathrm{~min}$ or more contained sufficient amounts of $\mathrm{H}_{2} \mathrm{O}_{2}$ and $\mathrm{NO}_{x}$ to inactivate the A. brasiliensis spores. Similar to direct plasma treatment, indirect plasma treatment by the PAW significantly damaged the fungal cell wall structure and reduced the viability of $A$. brasiliensis spores. SEM images and flow cytometric measurements indicate that cell wall structure in the PAW-treated spores was deformed and damaged with open holes. Disruption of the cell wall integrity provides a path where intracellular components can escape and RONS of the PAW directly attack intracellular components. Structural damage of the spore cell wall and degradation of genomic DNA by RONS in the PAW are critical processes that lead to cell death. Thus, we expect the fungicidal power of PAW could be applied to the disinfection of bioprotected melanized fungal spores that are recalcitrant to inactivation by diverse chemical agents. 
Author Contributions: S.H.K. (Seong Hwan Kim) and G.J.L. conceived and designed the experiments, analyzed the data, and wrote the manuscript. S.H.K. (Se Hoon Ki), H.N., G.R.A. and N.K.K. performed the experiments and research. E.H.C. provided assistance in the plasma setup and the analysis of plasma-induced RONS. All authors have read and agreed to the published version of the manuscript.

Funding: This research was supported by the Basic Science Research Program through the National Research Foundation of Korea (Grant numbers NRF-2016M3A7B4909823 (Kim), NRF-2018R1D1A1B07040386 (Lee)), by the Korea Ministry of Environments as "The Environmental Health Action Program" (2016001360002), and in part by Kwangwoon University in 2020.

Conflicts of Interest: The authors declare no conflict of interest.

\section{References}

1. O’Brien, H.E.; Parrent, J.L.; Jackson, J.A.; Moncalvo, J.M.; Vilgalys, R. Fungal community analysis by large-scale sequencing of environmental samples. Appl. Environ. Microbiol. 2005, 71, 5544-5550. [CrossRef]

2. Schmit, J.P.; Mueller, G.M. An estimate of the lower limit of global fungal diversity. Biodivers. Conserv. 2007, 16, 99-111. [CrossRef]

3. Hyde, K.D.; Al-Hatmi, A.M.S.; Andersen, B.; Boekhout, T.; Buzina, W.; Dawson, T.L., Jr.; Eastwood, D.C.; Jones, G.; de Hoog, S.; Kang, Y.; et al. The world's ten most feared fungi. Fungal Divers. 2018, 93, 161-194. [CrossRef]

4. $\quad$ Fisher, M.C.; Henk, D.A.; Briggs, C.J.; Brownstein, J.S.; Madoff, L.C.; McCraw, S.L.; Gurr, S.J. Emerging fungal threats to animal, plant and ecosystem health. Nature 2012, 484, 186-194. [CrossRef] [PubMed]

5. Ellis, D.; Davis, S.; Alexiou, H.; Handke, R.; Bartley, R. Descriptions of Medical Fungi; University of Adelaide: Adelaide, Australia, 2007.

6. Douglas, A.P.; Chen, S.C.A.; Slavin, M.A. Emerging infections caused by non-Aspergillus filamentous fungi. Clin. Microbiol. Infect. 2016, 22, 670-680. [CrossRef] [PubMed]

7. Snyder, A.B.; Worobo, R.W. Fungal spoilage in food processing. J. Food Protect. 2018, 81, 1035-1040. [CrossRef]

8. Curtis, L.; Lieberman, A.; Stark, M.; Rea, W.; Vetter, M. Adverse health effects of indoor molds. J. Nutr. Environ. Med. 2004, 14, 261-274. [CrossRef]

9. Boudaiffa, B.; Cloutier, P.; Hunting, D.; Huels, M.A.; Sanche, L. Resonant formation of DNA strand breaks by low-energy (3 to $20 \mathrm{eV}$ ) electrons. Science 2000, 287, 1658-1660.

10. Madugundu, G.S.; Park, Y.; Sanche, L.; Wagner, J.R. Radiation-induced formation of 2' ',3'-dideoxyribonucleosides in DNA: A potential signature of low-energy electrons. J. Am. Chem. Soc. 2012, 134, 17366-17368. [CrossRef]

11. Dobrynin, D.; Fridman, G.; Friedman, G.; Fridman, A. Physical and biological mechanisms of direct plasma interaction with living tissue. New J. Phys. 2009, 11, 115020. [CrossRef]

12. Li, Y.; Kang, M.H.; Uhm, H.S.; Lee, G.J.; Choi, E.H.; Han, I. Effects of atmospheric-pressure non-thermal bio-compatible plasma and plasma activated nitric oxide water on cervical cancer cells. Sci. Rep. 2017, 7, 45781. [CrossRef] [PubMed]

13. Iza, F.; Kim, G.J.; Lee, S.M.; Lee, J.K.; Walsh, J.L.; Zhang, Y.T.; Kong, M.G. Microplasmas: Sources, particle kinetics, and biomedical applications. Plasma Process. Polym. 2008, 5, 322-344. [CrossRef]

14. Lee, G.J.; Kwon, Y.W.; Kim, Y.H.; Choi, E.H. Raman spectroscopic study of plasma-treated salmon DNA. Appl. Phys. Lett. 2013, 102, 021911.

15. Lackmann, J.W.; Schneider, S.; Edengeiser, E.; Jarzina, F.; Brinckmann, S.; Steinborn, E.; Havenith, M.; Benedikt, J.; Bandow, J.E. Photons and particles emitted from cold atmospheric-pressure plasma inactivate bacteria and biomolecules independently and synergistically. J. R. Soc. Interface 2013, 10, 20130591. [CrossRef] [PubMed]

16. Laroussi, M. Low temperature plasma-based sterilization: Overview and state-of-the-art. Plasma Process. Polym. 2005, 2, 391-400. [CrossRef]

17. Liu, F.; Sun, P.; Bai, N.; Tian, Y.; Zhou, H.; Wei, S.; Zhou, Y.; Zhang, J.; Zhu, W.; Becker, K.; et al. Inactivation of bacteria in an aqueous environment by a direct-current, cold-atmospheric-pressure air plasma microjet. Plasma Process. Polym. 2010, 7, 231-236. [CrossRef]

18. Sun, P.; Wu, H.; Bai, N.; Zhou, H.; Wang, R.; Feng, H.; Zhu, W.; Zhang, J.; Fang, J. Inactivation of Bacillus subtilis spores in water by a direct-current, cold atmospheric-pressure air plasma microjet. Plasma Process. Polym. 2012, 9, 157-164. [CrossRef] 
19. Lee, G.J.; Choi, M.A.; Kim, D.; Kim, J.Y.; Ghimire, B.; Choi, E.H.; Kim, S.H. Influence of plasma-generated reactive species on the plasmid DNA structure and plasmid-mediated transformation of Escherichia coli cells. J. Appl. Phys. 2017, 122, 103303. [CrossRef]

20. Lee, G.J.; Sim, G.B.; Choi, E.H.; Kwon, Y.W.; Kim, J.Y.; Jang, S.; Kim, S.H. Optical and structural properties of plasma-treated Cordyceps bassiana spores as studied by circular dichroism, absorption, and fluorescence spectroscopy. J. Appl. Phys. 2015, 117, 023303. [CrossRef]

21. Kim, J.Y.; Lee, I.H.; Kim, D.; Kim, S.H.; Kwon, Y.W.; Han, G.H.; Cho, G.; Choi, E.H.; Lee, G.J. Effects of reactive oxygen species on the biological, structural, and optical properties of Cordyceps pruinosa spores. RSC Adv. 2016, 6, 30699-30709. [CrossRef]

22. Noh, H.; Kim, J.E.; Kim, J.Y.; Kim, S.H.; Han, I.; Lim, J.; Ki, S.H.; Choi, E.H.; Lee, G.J. Spore viability and cell wall integrity of Cordyceps pruinosa treated with an electric shock-free, atmospheric-pressure air plasma jet. Appl. Sci. 2019, 9, 3921. [CrossRef]

23. Los, A.; Ziuzina, D.; Boehm, D.; Cullen, P.J.; Bourke, P. Inactivation efficacies and mechanisms of gas plasma and plasma-activated water against Aspergillus flavus spores and biofilms: A comparative study. Appl. Environ. Microbiol. 2020, 86. [CrossRef] [PubMed]

24. Varga, J.; Kocsube, S.; Toth, B.; Frisvad, J.C.; Perrone, G.; Susca, A.; Meijer, M.; Samson, R.A. Aspergillus brasiliensis sp. nov., a biseriate black Aspergillus species with world-wide distribution. Int. J. Syst. Evol. Microbiol. 2007, 57, 1925-1932. [CrossRef] [PubMed]

25. Schuster, E.; Dunn-Coleman, N.; Frisvad, J.C.; van Dijck, P.W.M. On the safety of Aspergillus niger-A review. Appl. Microbiol. Biotech. 2002, 59, 426-435.

26. Yun, Y.H.; Hyun, M.W.; Suh, D.Y.; Kim, Y.M.; Kim, S.H. Identification and characterization of Eurotium rubrum isolated from Meju in Korea. Mycobiology 2009, 37, 251-257. [CrossRef]

27. Aamir, S.; Sutar, S.; Singh, S.K.; Baghela, A. A rapid and efficient method of fungal genomic DNA extraction, suitable for PCR based molecular methods. Plant Pathol. Quar. 2015, 5, 74-81. [CrossRef]

28. Giorgio, M.; Trinei, M.; Migliaccio, E.; Pelicci, P.G. Hydrogen peroxide: A metabolic by-product or a common mediator of ageing signals? Nat. Rev. Mol. Cell Biol. 2007, 8, 722-728. [CrossRef]

29. Farr, S.B.; Kogoma, T. Oxidative stress responses in Escherichia coli and Salmonella typhimurium. Microbiol. Mol. Biol. Rev. 1991, 55, 561-585. [CrossRef]

30. Uhm, H.S. Generation of various radicals in nitrogen plasma and their behavior in media. Phys. Plasmas 2015, 22, 123506. [CrossRef]

31. Uhm, H.S.; Na, Y.H.; Lee, C.B.; Choi, E.H.; Cho, G. Dissociation and excitation coefficients of nitrogen molecules and radical generation in nitrogen plasma. Curr. Appl. Phys. 2014, 14, S162-S166. [CrossRef]

32. Bibinov, N.; Knake, N.; Bahre, H.; Awakowicz, P.; Schulz-von der Gathen, V. Spectroscopic characterization of an atmospheric pressure $\mu$-jet plasma source. J. Phys. D Appl. Phys. 2011, 44, 345204. [CrossRef]

33. Deng, X.L.; Nikiforov, A.Y.; Vanraes, P.; Leys, C. Direct current plasma jet at atmospheric pressure operating in nitrogen and air. J. Appl. Phys. 2013, 113, 023305. [CrossRef]

34. Lukes, P.; Dolezalova, E.; Sisrova, I.; Clupek, M. Aqueous-phase chemistry and bactericidal effects from an air discharge plasma in contact with water: Evidence for the formation of peroxynitrite through a pseudo-second-order post-discharge reaction of $\mathrm{H}_{2} \mathrm{O}_{2}$ and $\mathrm{HNO}_{2}$. Plasma Sources Sci. Technol. 2014, 23, 015019. [CrossRef]

35. van Gils, C.A.J.; Hofmann, S.; Boekema, B.K.H.L.; Brandenburg, R.; Bruggeman, P.J. Mechanisms of bacterial inactivation in the liquid phase induced by a remote RF cold atmospheric pressure plasma jet. J. Phys. D Appl. Phys. 2013, 46, 175203. [CrossRef]

36. Ignarro, L.J.; Fukuto, J.M.; Griscavage, J.M.; Rogers, N.E.; Byrns, R.E. Oxidation of nitric oxide in aqueous solution to nitrite but not nitrate: Comparison with enzymatically formed nitric oxide from L-arginine. Proc. Natl. Acad. Sci. USA 1993, 90, 8103-8107. [CrossRef] [PubMed]

37. Pires, M.; Rossi, M.J.; Ross, D.S. Kinetic and mechanistic aspects of the $\mathrm{NO}$ oxidation by $\mathrm{O}_{2}$ in aqueous phase. Int. J. Chem. Kinet. 1994, 26, 1207-1227. [CrossRef]

38. Thirumdas, R.; Kothakota, A.; Annapure, U.; Siliveru, K.; Blundell, R.; Gatt, R.; Valdramidis, V.P. Plasma activated water (PAW): Chemistry, physico-chemical properties, applications in food and agriculture. Trends Food Sci. Technol. 2018, 77, 21-31. [CrossRef]

39. Bielski, B.H.J.; Cabelli, D.E.; Arudi, R.L.; Ross, A.B. Reactivity of $\mathrm{HO}_{2} / \mathrm{O}_{2}^{-}$radicals in aqueous solution. J. Phys. Chem. Ref. Data 1985, 14, 1041-1100. [CrossRef] 
40. de Grey, A.D.N.J. HO ${ }_{2}^{\bullet}$ : The forgotten radical. DNA Cell Biol. 2002, 21, 251-257. [CrossRef]

41. Apel, K.; Hirt, H. Reactive oxygen species: Metabolism, oxidative stress, and signal transduction. Annu. Rev. Plant Biol. 2004, 55, 373-399. [CrossRef]

42. Brieger, K.; Schiavone, S.; Miller, F.J.; Krause, K.H. Reactive oxygen species: From health to disease. Swiss Med. Wkly. 2012, 142, w13659. [CrossRef] [PubMed]

43. Szabo, C.; Ohshima, H. DNA damage induced by peroxynitrite: Subsequent biological effects. Nitric Oxide 1997, 1, 373-385. [CrossRef] [PubMed]

44. Arakaki, T.; Miyake, T.; Hirakawa, T.; Sakugawa, H. pH-dependent photoformation of hydroxyl radical and absorbance of aqueous-phase $\mathrm{N}$ (III) $\left(\mathrm{HNO}_{2}\right.$ and $\left.\mathrm{NO}_{2}^{-}\right)$. Environ. Sci. Technol. 1999, 33, 2561-2565. [CrossRef]

45. Riordan, E.; Minogue, N.; Healy, D.; O'Driscoll, P.; Sodeau, J.R. Spectroscopic and optimization modeling study of nitrous acid in aqueous solution. J. Phys. Chem. A 2005, 109, 779-786. [CrossRef] [PubMed]

46. Anastasio, C.; Chu, L. Photochemistry of nitrous acid ( $\mathrm{HONO})$ and nitrous acidium ion $\left(\mathrm{H}_{2} \mathrm{ONO}^{+}\right)$in aqueous solution and ice. Environ. Sci. Technol. 2009, 43, 1108-1114. [CrossRef] [PubMed]

47. Gaffney, J.S.; Marley, N.A.; Cunningham, M.M. Measurement of the absorption constants for nitrate in water between 270 and $335 \mathrm{~nm}$. Environ. Sci. Technol. 1992, 26, 207-209. [CrossRef]

48. Conner, E.M.; Grisham, M.B. Inflammation, free radicals, and antioxidants. Nutrition 1996, 12, $274-281$. [CrossRef]

49. Gessler, N.N.; Averyanov, A.A.; Belozerskaya, T.A. Reactive oxygen species in regulation of fungal development. Biochemistry 2007, 72, 1091-1109. [CrossRef]

50. Cherkas, A.; Holota, S.; Mdzinarashvili, T.; Gabbianelli, R.; Zarkovic, N. Glucose as a major antioxidant: When, what for and why it fails? Antioxidants 2020, 9, 140. [CrossRef]

51. Shen, B.; Jensen, R.G.; Bohnert, H.J. Mannitol protects against oxidation by hydroxyl radicals. Plant Physiol. 1997, 115, 527-532. [CrossRef]

52. Ghimire, B.; Lee, G.J.; Mumtaz, S.; Choi, E.H. Scavenging effects of ascorbic acid and mannitol on hydroxyl radicals generated inside water by an atmospheric pressure plasma jet. AIP Adv. 2018, 8, 075021. [CrossRef]

53. Johnston, I.R. The composition of the cell wall of Aspergillus niger. Biochem. J. 1965, 96, 651-658. [CrossRef] [PubMed]

54. Witteveen, C.F.B.; Visser, J. Polyol pools in Aspergillus niger. FEMS Microbiol. Lett. 1995, 134, 57-62. [CrossRef] [PubMed]

55. Ruijter, G.J.G.; Bax, M.; Patel, H.; Flitter, S.J.; van de Vondervoort, P.J.I.; de Vries, R.P.; van Kuyk, P.A.; Visser, J. Mannitol is required for stress tolerance in Aspergillus niger conidiospores. Eukaryot. Cell 2003, 2, 690-698. [CrossRef]

56. Mazu, T.K.; Bricker, B.A.; Flores-Rozas, H.; Ablordeppey, S.Y. The mechanistic targets of antifungal agents: An overview. Mini Rev. Med. Chem. 2016, 16, 555-578. [CrossRef] [PubMed]

57. Valiante, V.; Macheleidt, J.; Foge, M.; Brakhage, A.A. The Aspergillus fumigatus cell wall integrity signaling pathway: Drug target, compensatory pathways, and virulence. Front. Microbiol. 2015, 6, 325. [CrossRef]

58. Qin, G.; Liu, J.; Cao, B.; Li, B.; Tian, S. Hydrogen peroxide acts on sensitive mitochondrial proteins to induce death of a fungal pathogen revealed by proteomic analysis. PLoS ONE 2011, 6, e21945. [CrossRef]

59. Cadet, J.; Davies, K.J.A.; Medeiros, M.H.G.; Mascio, P.D.; Wagner, J.R. Formation and repair of oxidatively generated damage in cellular DNA. Free Radic. Biol. Med. 2017, 107, 13-34. [CrossRef]

60. Tubbs, A.; Nussenzweig, A. Endogenous DNA damage as a source of genomic instability in cancer. Cell 2017, 168, 644-656. [CrossRef]

61. Imlay, J.A.; Linn, S. DNA damage and oxygen radical toxicity. Science 1988, 240, 1302-1309. [CrossRef]

62. Burrows, C.J.; Muller, J.G. Oxidative nucleobase modifications leading to strand scission. Chem. Rev. 1998, 98, 1109-1152. [CrossRef] [PubMed]

(C) 2020 by the authors. Licensee MDPI, Basel, Switzerland. This article is an open access article distributed under the terms and conditions of the Creative Commons Attribution (CC BY) license (http://creativecommons.org/licenses/by/4.0/). 